\title{
METAL-CONTAINING NANOCOMPOSITES ON THE BASIS OF ISOTACTIC POLYPROPYLENE AND ETHYLENE-PROPYLENE-DIENE RUBBER
}

\author{
N.A.Alimirzayeva \\ Institute of Polymer Materials, NAS of Azerbaijan \\ ipoma@science.az
}

Received 27.05.2019

Accepted 30.09.2019

\begin{abstract}
The work summarizes the data of studies on the effect of nanofiller additives containing copper oxide nanoparticles stabilized by a high-pressure polyethylene matrix obtained by the mechanochemical method on the physico-mechanical, rheological properties and crystallization of thermoplastic mixed elastomers on the basis of isotactic polypropylene and ethylene propylene diene rubber. The prospects of using this additives to indicated elastomers that provides to the creation of a fine-spherical layered structure of the composition, characterized by improved melt flow rates, rheological, physicomechanical properties, and thereby expand the scope of application obtained nanocomposites.
\end{abstract}

Keywords: metal-containing nanocomposites, isotactic polypropylene, ethylene propylene diene rubber, copper oxide nanoparticles, physico-mechanical, rheological properties, crystallization.

doi

\section{Introduction}

In recent years, there has been considerable interest in composite materials based on polymer matrices and nanosized metal particles, that is due to a wide range of their application - from catalysis to nanotechnology in information technology.

The unique properties and improved characteristics of nanomaterials are due to their size, surface structure and interfacial interaction. The role played by particle size is comparable to that played by the chemical composition of particles, adding one more parameter to designing and process control [1-3].

The development of nanotechnology has opened up the possibility of conducting research in the field of composite nanomaterials and has now enabled the development and use of promising polymer materials for sensors, catalysis, nanoelectronics, which have specific physico-mechanical and operational properties: increased thermal and electrical conductivity, high magnetic susceptibi-lity, ability to shield ionizing radiation [4-6].

The use of nanoparticles of metals of variable valency (copper, cobalt, nickel etc.) in polymers allows to obtain fundamentally new materials which are widely used in radio and optoelectronics as magnetic, electrically conductive, and optical media $[4,7]$.
Among the polymer compositions, the mixtures based on polyolefins and rubbers have an important place. When the rubber content is up to $50-90 \%$, fundamentally new materials are formed - thermoplastic elastomers (TPE), which combine the mechanical properties of rubbers at normal temperatures with the processing ability, characteristic of linear thermoplastic polymers above their melting temperature [8]. The creation of TPE is a priority area of work in the field of polymer materials science.

The presented work is devoted to the preparation and study of the properties of nanocomposites on the based isotactic polypropylene (PP) and EPDM with using metal-containing nanoparticles (NP) stabilized by a polymer matrix as a nanofiller (NF).

\section{Experimental part}

In the work were used: isotactic PP of the TPPF79FB brand (Russia) with a melt yield strength of $10-15 \mathrm{~g} / 10 \mathrm{~min}$, according to Vicat softening temperature $\left(10 \mathrm{H}_{\mathrm{z}}\right)$ not more than $150^{\circ} \mathrm{C}$; EPDM of the Hüls brand with $\rho=0.86$ $\mathrm{g} / \mathrm{cm}^{3}$ containing $8 \%$ of ethylidene norbornene.

Copper I oxide $\left(\mathrm{Cu}_{2} \mathrm{O}\right) \mathrm{NP}$ stabilized by the polymer matrix of industrial high-pressure polyethylene obtained by the mechano-chemical method in a polymer melt were used as NF. The 
content of nanoparticles is 5 mass $\%$, size ( $25 \pm$ 1.0) $-\mathrm{nm}$, crystallinity $-35-45 \%[9,10]$. The ratio of the components of polymer mixtures (parts by weight): PP/EPDR/NF $=50 / 50 /(0.3$, 1.0, 3.0).

Nanocomposite polymeric materials were obtained by mixing PP with EPDM and coppercontaining NF on laboratory rollers at a temperature of $160-165^{\circ} \mathrm{C}$ for 15 minutes. For mechanical testing, the resulting mixtures were pressed in the form of plates $1 \mathrm{~mm}$ thick at $190^{\circ} \mathrm{C}$ and a pressure of $10 \mathrm{MPa}$.

Physico-mechanical parameters of the obtained compositions were determined on a RMI-250 device. The melt flow rate (MFR) was determined on an IIRT device at $T=200^{\circ} \mathrm{C}$, load equals to $5.0 \mathrm{~kg}$.

The crystallization of the obtained nanocomposite was studied by the dilatometric method [10].

The rheological properties of the melt of polymeric materials were measured in accordance with on a CEASTMF50 capillary rheometer (INSTRON, Italy).

SEM-analysis of the obtained compositions was carried out on a ZEISS device (Germany) [11].

\section{Results and its discussion}

The physico-mechanical and rheological properties of mixed TPE on the basis of PP/EPDM containing NF with NP of copper oxide are presented in Table.

Physico-mechanical and rheological parameters of nanocomposites

\begin{tabular}{|l|c|c|c|c|}
\hline \multicolumn{1}{|c|}{ Composition } & $\begin{array}{c}\sigma_{\mathrm{p},} \\
\mathrm{MPa}\end{array}$ & $\begin{array}{c}\varepsilon_{\mathrm{p}}, \\
\%\end{array}$ & $\begin{array}{c}\text { Vicat } \\
\text { softening } \\
\text { point, }{ }^{0} \mathrm{C}\end{array}$ & $\begin{array}{c}\text { MFI, } \\
\mathrm{g} / 10 \mathrm{~min}\end{array}$ \\
\hline PP/EPDM & 13.1 & 440 & 135 & 2.8 \\
\hline PP/EPDM/NF(0.3) & 13.7 & 420 & 140 & 3.7 \\
\hline PP/EPDM/NF(1.0) & 13.5 & 400 & 145 & 4.0 \\
\hline PP/EPDM/NF(3.0) & 12.6 & 380 & 140 & 5.6 \\
\hline
\end{tabular}

As can be seen from the data in the table. 1 , the introduction of $0.3-1.0 \mathrm{wt} . \% \mathrm{NF}$ into the composition leads to some increase in the strength index from 13.1 to $13.7 \mathrm{MPa}$. An increase in the NF concentration of more than 1.0 wt.\% leads to a decrease in the strength of the composite $(12.6 \mathrm{MPa})$, that is probably due to the aggregation of nanoparticles, which leads to the formation of microdefects in the bulk of the polymer matrix. An increase in the NF concentration leads to a decrease in the strain at break of the composite, which is apparently due to the blocking of the mobility of polymer segments by nanoparticles at the nanolevel.

A study of the Vicat softening point of the obtained compositions showed that the introduction of a nanofiller into the PP/EPDM composition leads to an increase in the heat resistance index from 135 to $145^{\circ} \mathrm{C}$, a further increase in amount of NF leads to a decrease in the heat resistance index, what is due probability to the microdefectiveness of the obtained composite. At the same time, an increase in the content of NF (1.0 - 3.0 parts by mass) contributes to an increase in MFI to 4.0 (1.0 parts by mass) and $5.6 \mathrm{~g} / 10 \mathrm{~min}$ (3.0 parts by mass), that indicates an improvement in the fluidity of the composition and the possibility of processing it by injection molding, extrusion, which expands the scope of its application.

The effect of a NF containing NP of copper oxide on the crystallization process of thermoplastic elastomer on the basis of isotactic PP and EPDM taken in the ratio (parts by mass): 50/50/1.0 by dilatometric method was studied [10].

Figure 1 shows the results of studying the temperature dependence of the specific volume of the initial PP, EPDM and their mixtures in a ratio of 50/50, as well as the $\mathrm{PP} / \mathrm{EPDR} / \mathrm{NF}$ nanocomposite.

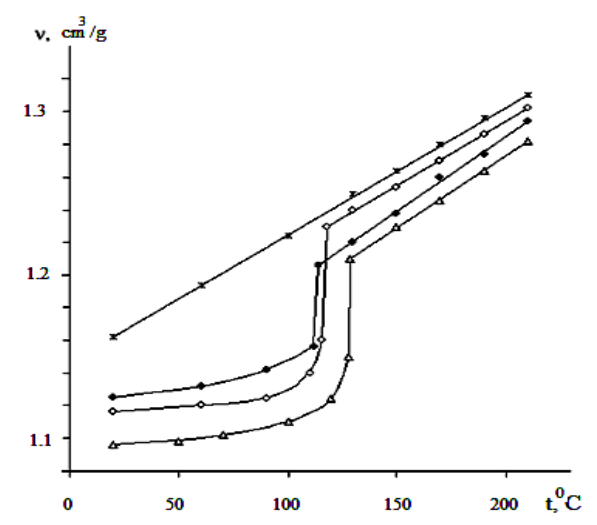

Fig. 1. Temperature dependence of the specific volume of the compositions $\Delta-$ initial PP, * initial EPDM, - $-\mathrm{PP} / \mathrm{EPDR}=50 / 50$, o $\mathrm{PP} / \mathrm{EPDR} / \mathrm{NF}(1.0)$. 
Analyzing the curves in this Figure, it can be seen that in the process of stepwise cooling of the sample PP as a representative of the class of semi-crystalline polymers at a crystallization temperature of $128^{\circ} \mathrm{C}$ has a characteristic sharp decrease in the specific volume from 1.21 to $1.14 \mathrm{~cm}^{3} / \mathrm{g}$, i.e. by $0.07 \mathrm{~cm}^{3} / \mathrm{g}$.

Such a sharp leap towards a decrease in the specific volume at the crystallization temperature is characterized as a first-order phase transition, i.e. transition from one state of aggregation into another. In this case, this transition is carried out from a viscous flowing state to a crystalline one.

The value of this index is important for the processing of polymer materials, since it approximately reflects the cooling (crystallization) process that takes place in the mold of an injection molding machine or in the molding head of an extruder. In addition, it allows to evaluate the shrinkage of the material during the production of structural items in the mold.

As expected, the initial EPDM, as an amorphous material, does not have a first-order phase transition and is characterized by a linear dependence of the specific volume on temperature. However, the introduction of synthetic rubber into the composition of PP leads to a significant change in the nature of the dependence of the dilatometric curve of the PP/EPDM composite, leading to a $13^{\circ} \mathrm{C}$ decrease in the temperature of the first-order phase transition. A decrease in the phase transition temperature in polymer mixtures is quite possible and is explained by the fact that the amorphous compo- nent, in this case, EPDM, slows down or interferes with the complete and free course of the PP crystallization process.

As a result of the studies it was shown that the introduction of copper NP contributes to an increase in the phase transition temperature by $3^{0} \mathrm{C}$. At the same time, it was found that at the crystallization temperature the specific volume decreases from 1.231 to $1.159 \mathrm{~cm}^{3} / \mathrm{g}$, i.e. by a value of $0.072 \mathrm{~cm}^{3} / \mathrm{g}$.

In fact, the introduction of NP into the composition of the polymer mixture helps to restore the crystallization process and its full course. The data obtained can be interpreted by the fact that NP contribute to the formation of heterogeneous nucleation centers in the composition melt, which, during stepwise cooling of the sample lead to, increasing a number of the crystallization centers, which generally lead to an improvement in the crystallization of PP and the formation of a relatively fine spherulite structure.

With the expansion of the possibilities of manufacturing large-sized automotive parts by high-speed injection molding, requirements for the rheological characteristics of polymer compositions are in the foreground.

From this point of view, it was interesting to establish how the mixing process of EPDM with isotactic PP and a metal-containing nanofiller can affect the change in their rheological characteristics [12].

Figure $2(a, b)$ shows the flow curves of the PP/EPDM polymer mixture and the $\mathrm{PP} / \mathrm{EPDR} / \mathrm{NF}$ composite on the basis of it.
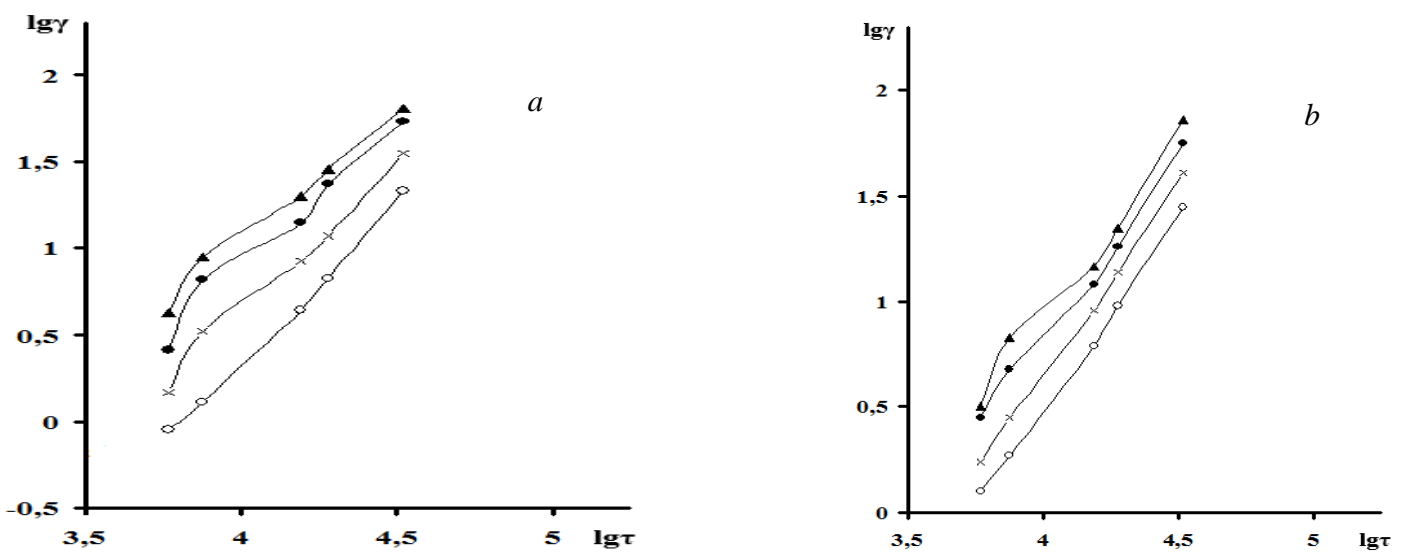

Fig. 2. The dependence of shear rate on shear stress $\operatorname{PP} / \operatorname{EPDR}(a), \operatorname{PP} / \operatorname{EPDR} / \mathrm{NF}(b)$ at different temperatures: $\circ-190, \times-210, \bullet-230, \boldsymbol{\Delta}-250{ }^{\circ} \mathrm{C}$. 

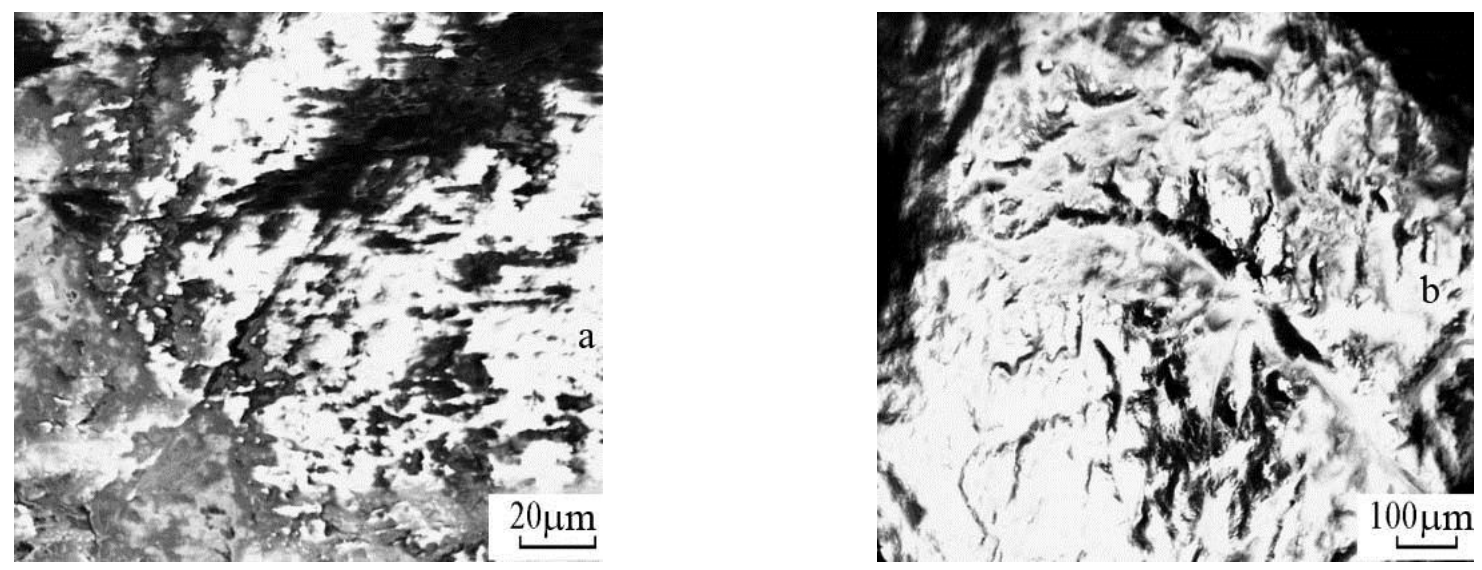

Fig. 3. SEM-images of sample structures: $a-\mathrm{PP} / \mathrm{EPDM}, b-\mathrm{PP} / \mathrm{EPDM} / \mathrm{NF}$.

From the rheograms in Figure $2(a, b)$ it can be seen that at low temperatures, the flow curves are linear, and at relatively high temperatures, the linear dependence of the shear rate on the shear stress is broken.

From a comparative analysis of the flow curves, it can be seen that when the PP/EPDM polymer mixture is filled with copper oxide nanoparticles at low temperatures, a regime close to the Newtonian regularity of the melt flow is observed, which is violated at rise of the temperature. An analysis of the rheograms showed that with the introduction of a nanofiller (1.0 parts by mass) into the composition of PP/EPDM, an increase in the shear rate of the composite melt is observed.

Thus, a study of the rheological properties of the obtained nanocomposites showed that the inclusion of a nanoscale filler in the polymer composite improves the melt flow, i.e. rheological properties, which facilitates the process of processing them by high-speed injection molding and helps to expand the manufacturing capabilities of large-sized automotive parts.

An SEM analysis of the obtained nanocomposites was carried out (Figures $3 a, b$ ).

Figure $3 a$ show a micrograph of the initial PP/EPDM mixture. It can be seen that the composite structure is compact spherulitic. The introduction of a nanofiller into the mixture promotes the formation of a finer spherulitic layered structure, that leads to an improvement of the fluidity of the nanocomposite and thereby to rheological properties (Figure $3 b$ ).
The prospects of using a nanofiller containing NPs of copper oxide stabilized by a high-pressure polyethylene matrix obtained by the mechanochemical method as an additive to TPE based on PP/EPDM is shown, which contribute to the creation of a fine-crystalline structure of the composition, and therefore its properties are improved and thereby expand fields of application of the obtained nanocomposite [11].

The prospects of using a nanofiller containing NP of copper oxide stabilized by a highpressure polyethylene matrix obtained by the mechanochemical method as an additive to TPE on the basis of PP/EPDM is shown to contribute to the creation of a fine-crystalline structure of the composition, and therefore its properties are improved and thereby expand a fild of the obtained nanocomposite.

\section{Conclusions}

New PP/EPDM-based nanocomposites were obtained using a copper-containing nanofiller produced by the mechano-chemical method stabilized by a high-pressure polyethylene polymer matrix, having improved strength characteristics and high values of melt flow rate, which indicates the possibility of processing it by high-speed casting under pressure and extrusion.

The crystallization process of the obtained nanocomposite was studied by the dilatometric method. It is shown that copper oxide nanoparticles introduced into the PP/EPDM composition contribute to the improvement of 
the crystallization of the system, while forming a relatively fine spherulite structure.

SEM-analysis of the prepared nanocomposites has been carried out. An appearance of a fine spherulitic layered structure in the polymer with metal-containing nanofillers favoring the improvement of properties of the prepared nanocomposites has been shown.

\section{References}

1. Joseph H. Koo. Polymer nanocomposites. Processing, characterization and applications. New York: McGraw-Hill. Nanoscience and Technology Series. 2006. 289 p.

2. Suzdalev. I.P., Suzdalev P.I. Nanoclusters and nanocluster systems. Advances in Chemistry. 2001. V. 70. No 3. P. 203-240.

3. Pomogailo A.D. Hybrid polymer - inorganic nanocomposites. Advances in chemistry. 2000. V. 6. No 1. P. 60-89.

4. Pomogailo A.D., Rosenberg A.S., Uflyand I.E. Metal nanoparticles in polymers. M.: Chemistry, 2000. 672 p.

5. Tretyakov A.O. Polymer nanocomposites materials of the 21st century. Equipment and tools for professionals. 2003. (37). No 2. P. 18-20.

6. Mikhaylin Yu.A. Polymer nanocomposite materials. Polymer materials. 2009. No 7. P. 10-13.

7. Gubin S.P., Yurkov G.Yu., Kosobudsky I.D. Nanomaterials вased on metal-containing nanoparti- cles in polyethylene and other carbon-chain polymers. International Journal of Materials and Product Technology. 2005. V. 23. No 1-2. P. 2-25.

8. Prut E.V., Erina N.A., Karger-Kocsis J., Medintseva T.I. Effects of Blend Composition and Dynamic Vulcanizationon the Morphology and Dynamic Viscoelastic Properties of PP/EPDM Blends. J. Appl. Polym. Sci. 2008. V. 109. P.1212-1220.

9. Kurbanova N.I, Alimirzoeva N.A., Guseinova Z.N., Nurullayeva D.R. Ecological Method of Preparation of Metal-Containing Nanoparticles in Polyethylene Matrix ITWCCST. 2017. Baku. Azerbaijan. 10-13 Sept. Book of Proceedings. P. 24-26.

10. Kurbanova N.I., Alimirzoeva N.A., Guseinova Z.N., Kuliyev A.M., Kakhramanov N.T., Gasanova A.A. Preparation and investigation of properties of metal-containing nanocomposites on the basis of isotactic polypropylene and ethylene propylene diene rubber. Processes of Petrochemistry and Oil Refining. 2018. V.19. No 3. P. 274-281.

11. Kurbanova N.I., Alimirzoyeva N.A., Kuliyev A.M., Guseinova Z.N., Ishenko N.Ya. Metal-containing Nanocomposites on the Basis of Isotactic Polypropylene. Inorganic materials: applied research. 2019. V. 10. No 2. P. 411-415.

12. Kurbanova N.I., Alimirzoeva N.A., Arzumanova N.B., Kachramanov N.T. Influence of metalcontaining nanofiller on rheological properties of mixed thermoelastoplasts on the basis of isotactic polypropylene and ternary ethylene-propylenediene elastomer. Processes of Petrochemistry and Oil Refining. 2019. V. 20. No 4. P. 254-260.

\section{IZOTAKTIK POLIPROPILEN Və ETILENPROPILENDIEN KAUÇUKU OSASLI METALTORKIBLI NANOKOMPOZITLOR \\ N.A.Olimirzoyeva}

İşdə tərkibində mexaniki-kimyəvi üsulla alınmış və yüksək təzyiq polietilenində stabilləşdirilmiş mis oksidi nanohissəcikləri (NH) saxlayan nanodoldurucu (ND) əlavəsinin izotaktik polipropilen (PP) və etilenpropilendien kauçuku (EPDK) əsaslı qarışı termoplastik elastomerlərin (TPE) fiziki-mexaniki, reoloji xassələrinə və kristallaşmasına təsiri üzrə aparılan tədqiqatlardan alınmış dəlillər ümumiləşdirilmişdir. Göstərilmişdir ki, TPE-yə mis oksidi nanohissəcikləri saxlayan nanodoldurucunun daxil edilməsi daha perspektlidir, beləki həmin əlavə kompozisiyada təbəqəli xırdasferolit struktur əmələ gətirməklə onun ərinti axıcıllğı göstəricisini, reoloji və fiziki-mexaniki xassələrini yaxşılaşdırır ki, bu da alınmış kompozisiyaların tətbiq sahələrini daha da genişləndirməyə imkan verir.

Açar sözlor: metaltarkibli nanokompozitlor, izotaktik polipropilen, etilenpropilendien kauçuku, mis oksidi nanohissaciyi, fiziki-mexaniki, reoloji xassalar, kristallaşma.

\section{МЕТАЛЛСОДЕРЖАЩИЕ НАНОКОМПОЗИТЫ НА ОСНОВЕ ИЗОТАКТИЧЕСКОГО ПОЛИПРОПИЛЕНА И ЭТИЛЕНПРОПИЛЕНДИЕНОВОГО КАУЧУКА}

\section{Н.А.Алимирзоева}

В работе обобщены данные проведенных исследований по влиянию добавок нанонаполнителей, содержащих наночастицы оксида меди, стабилизированные полимерной матрицей полиэтилена высокого давления, полученные механо-химическим методом, на физико-механические, реологические свойства и кристаллизацию смесевых термопластичных эластомеров на основе изотактического полипропилена и этиленпропилендиенового каучука. Показана перспективность использования этих добавок к указанным эластомерам, что способствует созданию мелкосферолитной слоистой структуры композиции, характеризующейся улучшенными показателями текучести расплава, реологическими, физико-механическими свойствами и тем самым расширению областей применения полученных нанокомпозитов.

Ключевые слова: металлсодержащие нанокомпозиты, изотактический полипропилен, этиленпропилендиеновый каучук, наночастицы оксида меди, физико-механические, реологические свойства, кристаллизация. 